\title{
A Conversation with Oliver Rando
}

\author{
InTERVIEWER: CARIKA WeLdon \\ Researcher, University of Oxford Wellcome Centre for Human Genetics
}

\begin{abstract}
Oliver Rando is a Professor in the Department of Biochemistry and Molecular Pharma-
\end{abstract} cology at the University of Massachusetts Medical School.

\section{Carika Weldon: Can you give us a brief summary of your work?}

Dr. Rando: The general area we work in is paternal effects in mammals: the effects of a male's environment on his offspring. We spend a lot of time working on different things that you can poke dads with that'll affect things like metabolism or anxiety-related behaviors in kids. We're trying to understand how this works: How what a dad sees or experiences affects information in sperm, how sperm information affects early development, and how that might ultimately give rise to a phenotype in the kids.

Carika Weldon: Just to clarify, this is not in humans, correct?

Dr. Rando: We work in mouse entirely.

Carika Weldon: And how exactly does the father's environment affect the child?

Dr. Rando: There are at least three different kinds of epigenetic information that make it into germ cells. There are small RNAs, there's DNA modification like cytosine methylation, and then there are histone modifications. The system we mostly focus on is dads eating a low-protein diet. In that system, we don't think there are many reproducible effects on DNA modification or on chromatin, so we are focused on small RNAs. We don't know for sure that small RNAs in sperm are responsible for programming offspring, although there are several other studies that have reported microinjecting sperm RNAs and getting phenotypes in kids. We haven't tried that yet. We've focused on characterizing the small RNAs that are in sperm and trying to figure out where they come from and what they do when they're in the embryo.

Carika Weldon: You're saying that if the father has a lowprotein diet, that then is a negative for the child?

Dr. Rando: In kids, we think it alters the levels of bile acids, so it affects the levels of hepatic cholesterol esters and it affects the levels of hepatic regulation of cholesterol biosynthesis genes. It affects glucose control. All of those things can be good or bad depending on whether or not the kid is seeing a scarce diet or a plentiful diet.
Another system I think is really useful for thinking about is it "good" or is it "bad" is we also studied paternal nicotine. Kids whose fathers consumed nicotine are resistant to a lethal injection of nicotine. Dads experiencing nicotine make kids nicotine-resistant. This is good if you're going to be injected with an $\mathrm{LD}_{50}$ of nicotine as a child, but those kids are also bad at glucose clearance. It's a trade-off. It's good if you think the kids are going to be seeing toxic levels of drugs in the environment. It's bad if you think that they're not going to be and they're trying not to get diabetes and metabolic syndrome.

Carika Weldon: Your work has focused on two RNAs: piRNAs [Piwi-interacting RNAs] and tRFs [transfer RNAderived RNA fragments]. Can you elaborate on those a bit more?

Dr. Rando: In the germline, the piRNAs are a pretty famous class of small RNAs; the testes are filled with them. It depends on the organism, but one of the roles they play is an antitransposon defense system. Sperm are unusual in the RNAs they carry because unlike most cells of the body, they carry some microRNAs - which is the most common small RNA in a typical fibroblast or hepatocyte or something - but they carry much more of these tRNA fragments, which are the $5^{\prime}$ ends of mature tRNAs. So, piRNAs are in the male germ cells, but ejaculated sperm carry these totally different tRNA fragments, which is sort of weird. That distinction actually led us to figure out where sperm RNAs come from. They actually aren't made during the process of sperm development in the testes. They're shipped into sperm as they spend a week or 2 weeks going through this long tube called the epididymis. As sperm leave the testes, they somehow eliminate all their piRNAs. As soon as we can get them in the very early epididymis, they've already gained tRNA fragments.

Carika Weldon: Do you know how that happens?

Dr. Rando: We don't know anything about how they lose piRNAs. We've assumed it's by degradation. But the way they gain tRNA fragments is that the epithelium of this tube makes tRNA fragments and we believe it ships them over in little vesicles called epididymisomes.

(C) 2019 Rando. This article is distributed under the terms of the Creative Commons Attribution-NonCommercial License, which permits reuse and redistribution, except for commercial purposes, provided that the original author and source are credited. 
Carika Weldon: But right before they are ejaculated, they gain back some piRNAs?

Dr. Rando: No, there's a third class of small RNAs in the picture. There's a small subset of microRNAs that is present in testicular sperm, absent in sperm in the early epididymis, and then present again in sperm in the late epididymis, which is really weird. It could be that sperm are dumping these RNAs in the early epididymis and then regaining them later, or a mixture of sperm could come out of the testes and the ones that are lacking these RNAs are getting stuck in the early epididymis. Those are the two models for it. But if you just purify sperm from the early and late epididymis, they differ mostly in the levels of a couple microRNAs.

Carika Weldon: In terms of your field, where do you see this going? Is it going toward a therapy?

Dr. Rando: Our interest is in understanding how dads talk to kids. Our model is that the epididymis ships RNA into sperm that will be delivered to the embryo. We also know that the conditions that a dad lives in affect the RNAs that are in the sperm. Putting those together, our model is that the epididymis senses the dad's environment somehow and changes the RNA it makes to give to sperm to give to kids. The million dollar question is "How does the epididymis 'see' the world?" How does its sensing of the world, of amino acid levels, or of leptin, or insulin, or something like that affect which RNAs it makes? That's a big basic question.

Is this something that one might manipulate to clinical ends? It's an interesting idea. It runs into many of the same concerns people might have with editing the genomes of kids; this would be editing the epigenome. That's above my pay grade, in terms of discussing whether society wants to do it or not. But it's certainly reasonable to test the idea that, by changing the RNAs you deliver to sperm, you would alter phenotypes in kids.

Carika Weldon: I recently did a school tour where children asked me questions about genetics. One of the best questions was "Half of you comes from your mom and half from your dad, but can you be more of one than the other?" What do you think, based on your work?

Dr. Rando: Generally speaking, we think of moms having more influence over kids than dads. That's certainly true, because in mammals babies grow inside of mom. Fetal alcohol syndrome is not magic and epigenetic; you're poisoning a baby. Also, women with diabetes have so-called "macrosomic" kids; they're just stewing in sugar and they get huge. In that sense, moms have a huge impact on kids that dads can't hope to replicate. In terms of the molecules in the germ cells, oocytes are where you inherit mitochondria from. Sperm are where you inherit $\mathrm{Y}$ chromosomes from. Beyond that, in terms of the small RNAs and the DNA modifications and stuff, it's still the case that probably more of what you inherit comes from the oocyte. Generally speaking, mom tries to erase as much of dad's information as possible.
Carika Weldon: So, when this RNA gets injected into the egg, the egg thinks, "This is not what we want; get rid of it," but it's literally getting rid of information that would have gone to the child?

Dr. Rando: The assumption until 10-15 years ago was that everything except for half a genome came from mom. I think that assumption is now $90 \%$ true. Most information is probably still coming through the oocyte, but at least some small amount of information comes through dad. One of the questions we're quite interested in is what the "bandwidth" of sperm is. Exactly how much information does dad manage to get through the mom's screen? Does he just tell kids quality of life: Life is crappy or great? Does he tell his kids about psychic stress, and water supply, and nutrition? Or does he tell his kids extremely detailed information about the world he lived in? This is a really deep question for the paternal effect field. We know some information makes it through, but the question of whether or not it's coarse-grained information or very fine-resolution information has very different implications.

Carika Weldon: Where do you see this field going in the next 10 to 15 years?

Dr. Rando: I'm very interested in how the epididymis sees the world and changes the RNAs it makes. In terms of our own work, the big black box is that we now see changes in gene control in the early embryo depending on which RNAs you give to the zygote. How those changes in gene regulation in an early embryo turn into a cholesterol phenotype in a pup is a question that we have ideas about, but we haven't addressed at all. I think that's the black box that the next decade or two is going to have to take seriously.

Carika Weldon: How did you get into this field? It's not your typical field at RNA meetings.

Dr. Rando: I started in chromatin and transcriptional control. One of the interesting things about chromatin is that, at least in some cases, it seems to carry epigenetic information at cell division. I was just starting my lab, and I was thinking about interesting things that epigenetics could do. Epigenetic information often listens to environmental conditions; the chromatin state changes when you heat-shock yeast or change their conditions. If any of this makes it through to the germ cells, that would allow the environment in one generation to affect the future. It was the kind of thing that people had started to talk about a lot speculatively, because it's reviving a very old question. We set out to test it, and it took a really long time to figure out a useful system for it.

Carika Weldon: How did your colleagues receive what you do in terms of your research?

Dr. Rando: I know there's a lot of skepticism. People don't express it to me personally that often, but when they do I try to take it positively. At this point, simply the observation that a paternal diet affects offspring metabolism has now been repeated in various ways in some- 


\section{A CONVERSATION WITH OLIVER RANDO}

thing like 100 publications. Just by the sheer mass of work, people are starting to believe that idea. I don't believe that we know the mechanisms by which this works in any great detail, so as to whether or not the mechanisms we're working on are going to ultimately be the correct answer for how dads talk to kids, I, myself, am skeptical. Some people believe that the small RNAs we work on might be the answer, and I'm sure lots of people don't. I don't know which of those people is correct.

Carika Weldon: You mentioned that there's some skepticism, and that happens in every area of science. It also happens when there's a big shift, when there's a result that doesn't fit with what everyone thinks. What do you want to say about that, in terms of how we should handle change and how we should handle not ignoring results because it doesn't fit what we think?

Dr. Rando: I don't have anything super-useful to say about that. The whole point of the scientific method is that you have to listen to the evidence, so I think most people ultimately will come around. The flip side of that is that if people have believed something for 100 years, then extraordinary claims require extraordinary evidence. It's very healthy to demand a high level of evidence for something that people suspected wasn't true. On the other hand, it's also the case that ultimately when the preponderance of evidence argues against your deeply held beliefs, you should really be paying attention to the evidence.

Carika Weldon: Your work can seem “out there," but you make it easy to listen to and to understand and accept. When you talk about science, how do you find that balance?

Dr. Rando: It's easy to talk about reproduction, because everybody can relate to reproductive biology one way or another. Personally, I'm actually quite shy. Giving a talk is sort of like acting. I have to feel like it's a performance. That's part of why I'm throwing my hands around and making lots of jokes. It keeps me comfortable. But it is the case that there are people who do amazing science but I just can't watch their talks. I get nothing out of their talks; I'd be better off reading papers than seeing the talk. The delivery means a lot because you don't realize how special a body of work is if people can't communicate that to you. Science communication is super-important for influencing how people think about the world. 


\section{$\$_{\text {CSH\& }}^{\infty}$ Cold Spring Harbor Symposia SYMPOSIA on Quantitative Biology}

\section{A Conversation with Oliver Rando}

Cold Spring Harb Symp Quant Biol published online March 13, 2020

Access the most recent version at doi:10.1101/sqb.2019.84.039651

$\mathbf{P}<\mathbf{P} \quad$ Published online March 13, 2020 in advance of the print journal.

Creative This article is distributed under the terms of the

Commons

License

http://creativecommons.org/licenses/by-nc/4.0/, which permits reuse and redistribution, except for commercial purposes, provided that the original author and source are credited.

Email Alerting Receive free email alerts when new articles cite this article - sign up in Service the box at the top right corner of the article or click here.

Advance online articles have been peer reviewed and accepted for publication but have not yet appeared in the paper journal (edited, typeset versions may be posted when available prior to final publication). Advance online articles are citable and establish publication priority; they are indexed by PubMed from initial publication. Citations to Advance online articles must include the digital object identifier (DOIs) and date of initial publication.

To subscribe to Cold Spring Harbor Symposia on Quantitative Biology go to: http://symposium.cshlp.org/subscriptions 